Research article

\title{
ESSENTIAL OILS AS POTENTIAL ANTI-STAPHYLOCOCCAL AGENTS
}

\author{
SZWEDA Piotr ${ }^{1, *}$, ZALEWSKA Magdalena $^{1}$, PILCH Joanna ${ }^{1}$, KOT Barbara ${ }^{2}$, \\ MILEWSKI Sławomir ${ }^{1}$
}

${ }^{1}$ Department of Pharmaceutical Technology and Biochemistry, Faculty of Chemistry, Gdansk University of Technology, G. Narutowicza Street 11/12, 80-233 Gdansk, Poland; ${ }^{2}$ Department of Microbiology, Faculty of Natural Sciences, Siedlce University of Natural Sciences and Humanities, 12 B. Prusa Street, Siedlce, Poland

(Received 07 June 2017, Accepted 12 February 2018)

Antibiotic therapy of staphylococcal mastitis is characterized by significantly lower cure rates compared to infections caused by other microorganisms. Thus, it is necessary to search for new, alternative, non-antibiotic agents that are effective in the eradication of these bacteria. The aim of our research was to investigate the antimicrobial, especially anti-staphylococcal potential of a large collection $(n=36)$ of essential oils (EOs). Investigation of the antimicrobial activity of tested oils was determined by using a serial, twofold dilution method in 96-wells microtiter plates under conditions recommended by the Clinical and Laboratory Standards Institute (CLSI). The preliminary analysis revealed that six oils, namely: Manuka, Thyme, Geranium, Cedar, Cinnamon (from bark) and Patchouli exhibited the highest activity against reference strains of bacteria. Significant anti-staphylococcal potential of these oils has been also confirmed for a group of 18 Staphylococcus aureus, 8 Staphylococcus epidermidis and 5 Staphylococcus xylosus strains isolated from cases of bovine mastitis. Especially high activity was observed for Cedar, Patchouli, Thyme and Manuka oils. The MIC (Minimal Inhibitory Concentration) values for Patchouli oil were in the concentrations range of 0.01 to $0.313 \%(\mathrm{v} / \mathrm{v})$. The three other oils inhibited the growth of staphylococci isolated from mastitis in the concentrations range of 0.01 to $0.625 \%$ (v/v). Oils isolated from Cinnamomum cassia and Pelargonium graveolens revealed a bit lower, but still satisfactory activity (MIC values in the concentrations range of 0.02 to $1.25 \%(\mathrm{v} / \mathrm{v})$ and from 0.078 to $1.25 \%(\mathrm{v} / \mathrm{v})$, respectively). In many cases a slightly higher concentration of oils was required to obtain the bactericidal effect in comparison to growth inhibition. The time - kill kinetic assay revealed that the bactericidal effect was achieved after two hours incubation of the reference strain $S$. aureus PCM 2051 cells with Thyme oil at concentration equal to $2 \mathrm{xMIC}(1.25 \%(\mathrm{v} / \mathrm{v}))$ or MIC $(0.625 \%(\mathrm{v} / \mathrm{v}))$. A slightly lower activity was observed in the case of Cinnamon oil, the bactericidal effect was achieved after 8 hours of incubation. The results of our research clearly indicate that some essential oils exhibit a promising antimicrobial activity and can be considered as alternative antistaphylococcal agents.

Key words: Staphylococci, bovine mastitis, essential oils

\footnotetext{
*Corresponding author: e-mail: piotr.szweda@wp.pl
} 


\section{INTRODUCTION}

Staphylococci belong to the most common and most dangerous factors responsible for bovine mastitis. Infections caused by the bacteria belonging to this genus are especially difficult to treat, mainly due to evolved mechanisms of resistance to antimicrobial drugs. High level of antibiotic resistance of staphylococci recovered from mastitis is well documented worldwide, including several reports from Poland [1-6]. Because of rapidly growing number of isolates of staphylococci resistant to a plethora of antibiotics currently in use for human and animal therapies, there is an urgent need for investigation and development of new alternative therapeutics. Many authors from different world regions have recently shown that natural products of different origins exhibit a strong potential to control and treat infections caused by this group of bacteria. The promising natural products and substances that exhibit antistaphylococcal (including MRSA isolates) activity include: compounds of bacterial origin e.g. bacteriocins [7] and peptidoglycan hydrolases [6,8], bacteriophages $[9,10]$, compounds of animal origin e.g. renelaxin [11], and finally compounds of plant origin: flavonoids - heterocyclic compound of plant pigments, plant extracts, essential oils [12-14] but also honey and propolis (which by some authors are classified as products of animal origin, however both these products are collected by bees from plant sources) [15-17]. The issue of alternative therapies for diseases of staphylococcal etiology has been recently widely discussed by Kurlenda and Grinholc [18]. The compounds isolated from plant origin, especially essential oils, seem to be the most promising considering their application for both prevention and treatment of staphylococcal infections [16]. Essential oils are aromatic and volatile liquids extracted from different parts of plants e.g. leaves, roots, buds or barks. They are secondary products of plant metabolism used as a defense mechanism against plants pathogens [19]. Thus they are considered as substances with strong antimicrobial potential. Some of them are produced constantly, while others are produced as an answer to microbial infection or tissue injury (to protect against microbial entrance). In consideration of EOs' potential application in medicine we share the opinion presented by Kurlenda and Grinholc [18], that the majority of natural products, including essential oils, display properties that make them potential candidates for topical rather than systemic drugs, e.g. as components of bioactive wound dressing materials, ointments and gels.

The aim of our study was to examine the antimicrobial activity of a large group $(n=36)$ of essential oils from different botanical sources against $S$. aureus isolates recovered from clinical cases of bovine mastitis. The carried out research revealed that some oils seem to be promising candidates for alternative antistaphylococcal agents, yet further studies, e.g. cytotoxicity tests are required.

\section{MATERIALS AND METHODS}

\section{Strains, media and oils}

The preliminary investigation on the antimicrobial activity of essential oils was carried out against four, commercially available, reference strains of bacteria: S. aureus PCM 
2051, S. epidermidis PCM 2118, Pseudomonas aeruginosa ATCC 27853, Escherichia coli K12. For research purposes we used a set of 36 commercially available essential oils (purchased from Pollena Aroma Poland) which were previously tested by our group for their antifungal activity [20]. Six of the most effective oils were selected for further analysis of their activity against $18 \mathrm{~S}$. aureus, $8 \mathrm{~S}$. epidermidis and $5 \mathrm{~S}$. xylosus strains recovered from clinical cases of bovine mastitis. The $S$. aureus isolates were previously investigated in our laboratory, and each of the strains revealed resistance to at least one antibiotic commonly used for the treatment of bovine mastitis [6]. All strains of bacteria (including reference strains) were routinely grown on Mueller-Hinton Agar (MHA) plates and during the assays of susceptibility to essential oils in Mueller-Hinton Broth 2 - cation adjusted (MHB2) - both purchased from Sigma (Sigma-Aldrich Corp., St. Louis, MO, U.S.A.).

\section{Determination of MIC and MBC values for selected oils against reference and clinical strains of bacteria}

The investigation of the antimicrobial activity of examined essential oils was determined using a serial, two-fold dilution method in 96-wells microtiter plates under conditions recommended by the Clinical and Laboratory Standards Institute (CLSI). The aim of the method is the determination of the MIC parameter (Minimal Inhibitory Concentration) - the minimal concentration of the tested agent which is able to inhibit the growth of the specified strain of bacteria. The $100 \mu \mathrm{l}$ of twofold dilutions of tested oils (in the concentration range of $5.0 \%(\mathrm{v} / \mathrm{v})$ to $0.0097 \%$ $(\mathrm{v} / \mathrm{v}))$ were carried out in the wells using MHB2 medium. The pure cultures of both reference bacterial strains, and mastitis isolates were grown on the MHA agar for 18 -24 hours at $37^{\circ} \mathrm{C}$. A small amount of the biomass of the culture of each strain of microorganisms was suspended in sterile PBS (phosphate buffered saline, $\mathrm{pH} 7.4$ at $25{ }^{\circ} \mathrm{C}$, purchased from Sigma) solution to get the optical density $\mathrm{OD}_{600}=0.13$ (equal to cell concentration approximately $\left.1 \times 10^{8} \mathrm{CFU} / \mathrm{ml}\right)$. The obtained suspensions of the cells were next diluted 1:100 (v/v) in the MHB2 medium. A $100 \mu$ l of the obtained cells suspension was finally loaded into the wells of the plates prepared in advance containing two-fold dilutions of tested oils. The final concentration of the cells in all wells was approximately $5 \times 10^{5} \mathrm{CFU} / \mathrm{ml}$. The positive growth control of each strain was performed in the wells not containing the tested oils. The negative control containing only the media was included in each assay. Microtiter plates were incubated at $37^{\circ} \mathrm{C}$ for 24 hours. Following the incubation period the determination of the MIC values of the tested agents were carried out by measuring the absorbance at $531 \mathrm{~nm}$ using a Victor $^{3}$ microplate reader (PerkinElmer, Inc., Waltham, MA, U.S.A.). The lowest concentration of the oil causing inhibition of growth equal or higher than 90 $\%$ (MIC90) of growth control was taken as the MIC value. Each test was repeated three times.

The Minimal Bactericidal Concentration (MBC) value was established by sub-culturing a small amount of growing medium from each well of all microtiter plates on Baird Parker agar medium. The transfer of growing medium from the wells was performed 
using a replica plater. The Petri dishes with inoculated Baird Parker agar were incubated at $37^{\circ} \mathrm{C}$ for 24 hours. The MBC was defined as the lowest oil concentration where no bacterial growth was seen on an agar plate. Each test was repeated three times.

\section{Time - kill assay}

Sterile MHB2 medium (5 ml) was inoculated with a fresh culture of $S$. aureus PCM 2051 to the final concentration of the cells of approximately $5 \times 10^{5}-1 \times 10^{6} \mathrm{CFU} /$ $\mathrm{ml}$. The cells were exposed to Thyme or Cinnamon oils at concentrations equal to MIC and 2xMIC. Suspensions of the treated cells were incubated at $37{ }^{\circ} \mathrm{C}$ without shaking. At predetermined time points: 0, 2, 4, 8, 24, 48 and 72 hours a 100- $\mu$ l aliquot was taken from each of the cells suspensions treated with the oils and streaked on Baird Parker agar plates. At time points 2, 4 and 8 hours dilutions of each suspension were prepared in a sterile PBS solution in the range of $10^{-1}$ to $10^{-3}$ and $100-\mu \mathrm{l}$ aliquots from these dilutions were streaked on the Baird Parker agar plate. The cells' suspension in MHB2 medium not treated with the oils was used as the bacteria growth control. At the same time points a $100-\mu \mathrm{l}$ aliquot was taken from the control suspension and appropriately diluted in sterile PBS solution. The $100-\mu$ l aliquots from $10^{-5}$ to $10^{-7}$ dilutions were streaked on the Baird Parker agar plate. Colony counts were determined after incubation at $37^{\circ} \mathrm{C}$ for 24 hours.

\section{RESULTS AND DISCUSSION}

The preliminary, screening analysis revealed that six out of 36 investigated oils, namely: Cedar (Juniperus virginiana), Cinnamon (Cinnamomum cassia from bark), Geranium (Pelargonium graveolens), Manuka (Leptospermum scoparium), Patchouli (Pogostemon cablin) and Thyme (Thymus vulgaris) exhibited a promising activity (Tab. 1.). The MIC values for these oils were in the range of concentrations from $0.01 \%$ to $2.5 \%(\mathrm{v} / \mathrm{v})$ against at least one of the tested reference strains of bacteria. S. epidermidis PCM 2118 revealed the highest susceptibility, with MIC values in the range of 0.01 to $0.156 \%(\mathrm{v} / \mathrm{v}))$ and E. coli K12 was found as most resistant. Manuka, Patchouli and Cedar oils were not able to inhibit the growth of this strain of bacteria in the tested range of concentrations. Geranium oil inhibited the growth of E. coli at a concentration of $1.25 \%(\mathrm{v} / \mathrm{v})$ and MIC for Thyme and Cinnamon oils was $0.625 \%(\mathrm{v} / \mathrm{v})$. MBC values for reference strains were not determined.

Table 1. Activity of essential oils against reference strains of bacteria: S. aureus PCM 2051 (SA), S. epidermidis PCM 2118 (SE), P. aeruginosa ATCC 27853 (PA), E. coli K12 (EC)

\begin{tabular}{ccccccc}
\hline \multirow{2}{*}{ Strain } & \multicolumn{7}{c}{ MIC values of Essential Oils [\%](v/v) } \\
\cline { 2 - 7 } & Geranium & Cinnamon & Cedar & Patchouli & Thyme & Manuka \\
\hline SA & 1.250 & 0.625 & 0.313 & 0.625 & 0.625 & 0.625 \\
SE & 0.156 & 0.078 & 0.020 & 0.005 & 0.005 & 0.039 \\
EC & 1.250 & 0.625 & $>2.500$ & $>2.500$ & 0.625 & $>2.500$ \\
PA & 0.625 & 0.313 & 1.250 & 0.313 & 0.625 & 0.313 \\
\hline
\end{tabular}


Table 2. Activity of essential oils against staphylococci isolated from bovine mastitis

\begin{tabular}{|c|c|c|c|c|c|c|c|c|c|c|c|c|}
\hline \multirow{3}{*}{ Strain } & \multicolumn{12}{|c|}{ MIC and MBC of Essential Oils [\%](v/v) } \\
\hline & \multicolumn{2}{|c|}{ Geranium } & \multicolumn{2}{|c|}{ Cinnamon } & \multicolumn{2}{|c|}{ Cedar } & \multicolumn{2}{|c|}{ Patchouli } & \multicolumn{2}{|c|}{ Thyme } & \multicolumn{2}{|c|}{ Manuka } \\
\hline & MIC & MBC & MIC & MBC & MIC & MBC & MIC & MBC & MIC & MBC & MIC & MBC \\
\hline & \multicolumn{12}{|c|}{ Staphylococcus aureus } \\
\hline$\overline{\mathrm{SA}} 1$ & 0.313 & 2.500 & 0.156 & 0.313 & 0.010 & 0.010 & 0.010 & 0.020 & 0.078 & 0.156 & 0.078 & 0.156 \\
\hline SA 5 & 0.156 & 0.156 & 0.313 & 0.313 & 0.010 & 0.010 & 0.010 & 0.010 & 0.039 & 0.039 & 0.156 & 0.313 \\
\hline SA 9 & 0.625 & 2.500 & 0.625 & 1.250 & 0.010 & 0.020 & 0.010 & 0.010 & 0.039 & 0.039 & 0.005 & 0.313 \\
\hline SA 11 & 0.078 & 0.156 & 0.156 & 0.156 & 0.039 & 0.078 & 0.020 & 0.078 & 0.039 & 0.078 & 0.078 & 0.313 \\
\hline SA 15 & 0.625 & 0.625 & 0.625 & 0.625 & 0.156 & 0.156 & 0.156 & 0.156 & 0.313 & 0.313 & 0.156 & 0.625 \\
\hline SA 27 & 1.250 & 1.250 & 0.625 & 0.625 & 0.078 & 0.078 & 0.078 & 0.078 & 0.156 & 0.156 & 0.313 & 0.313 \\
\hline SA 29 & 1.250 & 1.250 & 0.313 & 0.625 & 0.010 & 0.010 & 0.010 & 0.010 & 0.010 & 0.020 & 0.039 & 0.078 \\
\hline SA 38 & 0.625 & 1.250 & 0.625 & 1.250 & 0.010 & 0.010 & 0.010 & 0.010 & 0.010 & 0.010 & 0.010 & 0.078 \\
\hline SA 39 & 0.313 & 0.313 & 0.313 & 0.313 & 0.020 & 0.020 & 0.020 & 0.020 & 0.039 & 0.078 & 0.078 & 0.078 \\
\hline SA 53 & 0.156 & 0.313 & 0.625 & 0.625 & 0.010 & 0.010 & 0.020 & 0.039 & 0.039 & 0.078 & 0.078 & 0.625 \\
\hline SA 54 & 0.313 & 0.313 & 0.313 & 0.625 & 0.010 & 0.010 & 0.010 & 0.010 & 0.020 & 0.039 & 0.078 & 1.250 \\
\hline SA 70 & 0.156 & 0.156 & 0.625 & 0.625 & 0.156 & 0.156 & 0.039 & 0.039 & 0.039 & 0.078 & 0.156 & 0.313 \\
\hline SA 83 & 0.625 & 0.625 & 0.625 & 0.625 & 0.625 & 0.625 & 0.313 & 0.313 & 0.625 & 0.625 & 0.625 & 0.625 \\
\hline SA 84 & 0.313 & 0.313 & 0.156 & 0.313 & 0.020 & 0.020 & 0.010 & 0.010 & 0.039 & 0.078 & 0.020 & 0.313 \\
\hline SA 86 & 1.250 & 1.250 & 1.250 & 1.250 & 0.156 & 0.156 & 0.078 & 0.078 & 0.078 & 0.156 & 0.156 & 0.156 \\
\hline SA 102 & 1.250 & 2.500 & 1.250 & 1.250 & 0.020 & 0.020 & 0.020 & 0.078 & 0.039 & 0.078 & 0.156 & 0.313 \\
\hline SA 103 & 0.313 & 0.313 & 0.313 & 0.313 & 0.010 & 0.010 & 0.010 & 0.010 & 0.156 & 0.156 & 0.313 & 0.313 \\
\hline SA 105 & 0.313 & 1.250 & 0.625 & 0.625 & 0.010 & 0.010 & 0.010 & 0.010 & 0.005 & 0.625 & 0.039 & 1.250 \\
\hline
\end{tabular}

Staphylococcus epidermidis

\begin{tabular}{lllllllllllll}
\hline SE 223 & 0.625 & 0.625 & 0.039 & 0.078 & 0.313 & 2.500 & 0.313 & 1.250 & 0.156 & 0.313 & 0.005 & 0.078 \\
SE 267 & 0.625 & 0.625 & 0.625 & 0.625 & 0.625 & 1.250 & 0.313 & 1.250 & 0.313 & 0.313 & 0.078 & 0.156 \\
SE 30 & 0.625 & 0.625 & 0.313 & 0.313 & 0.020 & 0.078 & 0.020 & 0.020 & 0.020 & 0.039 & 0.005 & 0.010 \\
SE 56 & 0.625 & 0.625 & 0.156 & 0.156 & 0.039 & 0.156 & 0.039 & 0.039 & 0.039 & 0.078 & 0.625 & 0.625 \\
SE 69A & 0.313 & 0.625 & 0.156 & 0.156 & 0.078 & 0.156 & 0.020 & 0.039 & 0.020 & 0.078 & 0.078 & 0.078 \\
SE 80 & 0.156 & 1.250 & 0.156 & 0.625 & 0.020 & 0.039 & 0.039 & 0.156 & 0.156 & 0.625 & 0.313 & 0.625 \\
SE 95 & 0.625 & 1.250 & 0.625 & 0.625 & 0.156 & 0.313 & 0.156 & 0.313 & 0.313 & 0.625 & 0.039 & 0.078 \\
SE & 1.250 & 1.250 & 0.625 & 0.625 & 0.078 & 0.625 & 0.078 & 0.625 & 0.156 & 0.625 & 0.005 & 0.078 \\
M7A1 & & & & & & & & & Staph
\end{tabular}

Staphylococcus xylosus

\begin{tabular}{lrrrrrrrrrrrr}
\hline $8 \mathrm{~J}(\mathrm{~S})$ & 0.156 & 0.313 & 0.020 & 0.039 & 0.010 & 0.039 & 0.010 & 0.010 & 0.010 & 0.010 & 0.078 & 0.078 \\
$56 \mathrm{~B}(\mathrm{~S})$ & 0.156 & 0.313 & 0.078 & 0.156 & 0.156 & 0.156 & 0.078 & 0.156 & 0.078 & 0.156 & 0.313 & 0.313 \\
$65 \mathrm{C}(\mathrm{S})$ & 0.156 & 0.313 & 0.313 & 0.313 & 0.078 & 0.313 & 0.020 & 0.078 & 0.020 & 0.078 & 0.078 & 0.156 \\
$70 \mathrm{~B}(\mathrm{~S})$ & 0.625 & 0.625 & 0.625 & 0.625 & 0.313 & 0.313 & 0.156 & 0.156 & 0.313 & 0.313 & 0.313 & 0.313 \\
$\mathrm{M} 2 \mathrm{~B}(\mathrm{~S})$ & 0.313 & 0.313 & 0.078 & 0.078 & 0.039 & 0.039 & 0.039 & 0.039 & 0.039 & 0.078 & 0.313 & 0.313 \\
$\begin{array}{l}\text { Number } \\
\text { of shifts }\end{array}$ & 13 & & 10 & & 12 & & & 12 & & 21 & & 19 \\
\hline
\end{tabular}


High anti-staphylococcal potential of these six oils has been also confirmed for the group of 31 strains recovered from bovine mastitis (Tab. 2). In the case of 18 S. aureus isolates definitely the highest activity was exhibited by oils isolated from $P$. cablin and J. virginiana. Both of these oils inhibited the growth of nine $S$. auereus isolates $(50 \%)$ at a concentration as low as $0.01 \%(\mathrm{v} / \mathrm{v})$. The growth of most resistant strains was inhibited at a concentration of $0.312 \%(\mathrm{v} / \mathrm{v})$ in the case of Patchuli oil and $0.625 \%$ $(\mathrm{v} / \mathrm{v})$ in the case of Cedar oil (one isolate in each case). High activity was exhibited also by the oil isolated from T. vulgaris. The MIC value of this product for $8(44.4 \%)$ isolates was $0.039 \%(\mathrm{v} / \mathrm{v})$ and growth of three $(16.7 \%)$ strains was inhibited at a concentration of $0.01 \%(\mathrm{v} / \mathrm{v})$. A comparable activity was exhibited by the oil produced from L. scoparium. The lowest tested concentration $0.01 \%(\mathrm{v} / \mathrm{v})$ inhibited the growth of two $(11.1 \%)$ isolates, and only three $(16.7 \%)$ strains required a concentration higher than $0.156 \%(\mathrm{v} / \mathrm{v})$. A bit lower, but still interesting, activity was observed in the case of the last two oils isolated from $P$. graveolens and $C$. cassia. The MIC values for these oils were in the concentration range of 0.078 to $1.25 \%(\mathrm{v} / \mathrm{v})$ and from 0.156 to $1.25 \%(\mathrm{v} / \mathrm{v})$, respectively. The activity of the oils against $S$. epidermidis and $S$. xylosus was similar as in the case of $S$. aureus isolates. Four oils: Cedar, Patchouli, Manuka and Thyme exhibited slightly higher activity in comparison to Cinnamon and Geranium oils. However, S. epidermidis isolates exhibited slightly lower susceptibility in the case of Patchuli and Cedar oils and S. xylosus strains were more resistant to Manuka oil components. Some of the clinical isolates, e. g. SA15, SA83 and SA70 exhibited a considerably higher resistance in comparison to other strains tested.

Table 3. Susceptibility of different species of staphylococci isolated from mastitis to selected essential oils

\begin{tabular}{|c|c|c|c|c|c|c|c|c|c|c|c|c|c|c|c|c|c|c|}
\hline Number of & & eus & u. & $\begin{array}{l}S . \\
\text { ler }\end{array}$ & $\begin{array}{l}\text { pide } \\
\text { artict }\end{array}$ & $\begin{array}{l}\text { ut } \\
\text { ul }\end{array}$ & $\begin{array}{l}\text { dis (S } \\
\text { conc }\end{array}$ & $\begin{array}{l}\text { SE) } \\
\text { cen }\end{array}$ & & $\begin{array}{l}\text { osus } \\
\text { of } \mathrm{E}\end{array}$ & $\begin{array}{l}\text { (SX) } \\
\text { ssent }\end{array}$ & $\begin{array}{l}\text { strair } \\
\text { ial O }\end{array}$ & $\begin{array}{l}\text { ns } \\
\text { iil }\end{array}$ & bit & $\mathrm{gg}$ & MIC & $C$ & \\
\hline Concentration & & ranit & & Cin & inam & non & & Ced & & & tcho & & & hym & & & Ianu & aka \\
\hline$[\%](v / v)$ & SA & SE & SX & SA & $\mathrm{SE}$ & SX & SA & SE & SX & SA & SE & SX & SA & SE & SX & SA & $\mathrm{SE}$ & $\mathrm{SX}$ \\
\hline 0.01 & 0 & 0 & 0 & 0 & 0 & 0 & 9 & 0 & 1 & 9 & 0 & 1 & 3 & 0 & 1 & 2 & 3 & 0 \\
\hline 0.02 & 0 & 0 & 0 & 0 & 0 & 1 & 3 & 2 & 0 & 4 & 2 & 1 & 1 & 2 & 1 & 1 & 0 & 0 \\
\hline 0.039 & 0 & 0 & 0 & 0 & 1 & 0 & 1 & 1 & 1 & 1 & 1 & 1 & 8 & 1 & 1 & 2 & 1 & 0 \\
\hline 0.078 & 1 & 0 & 0 & 0 & 0 & 2 & 1 & 2 & 1 & 2 & 2 & 1 & 2 & 0 & 1 & 5 & 2 & 2 \\
\hline 0.156 & 3 & 1 & 0 & 3 & 3 & 0 & 3 & 1 & 1 & 1 & 1 & 1 & 2 & 3 & 0 & 5 & 0 & 0 \\
\hline 0.312 & 6 & 1 & 3 & 5 & 1 & 1 & 0 & 1 & 1 & 1 & 1 & 0 & 1 & 2 & 1 & 2 & 1 & 3 \\
\hline 0.625 & 4 & 5 & 1 & 8 & 3 & 1 & 1 & 1 & 0 & 0 & 1 & 0 & 1 & 0 & 0 & 1 & 1 & 0 \\
\hline 1.25 & 4 & 1 & 1 & 2 & 0 & 0 & 0 & 0 & 0 & 0 & 0 & 0 & 0 & 0 & 0 & 0 & 0 & 0 \\
\hline
\end{tabular}

In the case of many strains some shift of MBC (Minimal Bactericidal Concentration) value of the oils has been observed in comparison to the value of concentration, which effectively inhibited the growth of the cells (MIC). This means that a higher concentration of oils constituents was required for killing bacteria in comparison to the 
concentrations that enable the bacteriostatic effect. The highest number of shifts of MBC values in comparison to MIC values was observed for Thyme and Manuka oils, for 21 and 19 isolates, respectively. It also should be noticed that the shifts appeared especially often in the case of $S$. epidermidis isolates. However, the MBC values off all oils were still on a relatively low level (below 1.25\% (v/v)).

Finally, the activity of two selected oils: Thyme (found as one of the most active) and Cinnamon (found as one with rather moderate potential) was evaluated with the time - kill assay (Fig.1). The result proved a considerably higher activity of the oil isolated from T. vulgaris. Already after two hours of incubation no living cells of the reference $S$. aureus PCM 2051 strain were observed in the suspension containing the oil at a concentration equal to MIC $(0.625 \%(\mathrm{v} / \mathrm{v})$ and $2 \mathrm{xMIC}(1.25 \%(\mathrm{v} / \mathrm{v})-$ no colonies were observed on Baird Parker agar plates inoculated with these suspensions (Fig 1). In the case of Cinnamon oil the number of bacterial cells decreased during the incubation time. However, the decrease of the number of living cells in both suspensions (containing the oil at concentrations equal to MIC or 2xMIC) after two hours of incubation was very low in comparison to the control suspension (not treated with any agent). The complete elimination of living cells from both suspensions containing Cinnamon oil was achieved after eight hours of incubation (Fig 1). No living cells were detected in all suspensions treated with both oils (at concentrations equal to MIC or 2xMIC) after 24, 48 and 72 hours of incubation (Fig. 1).

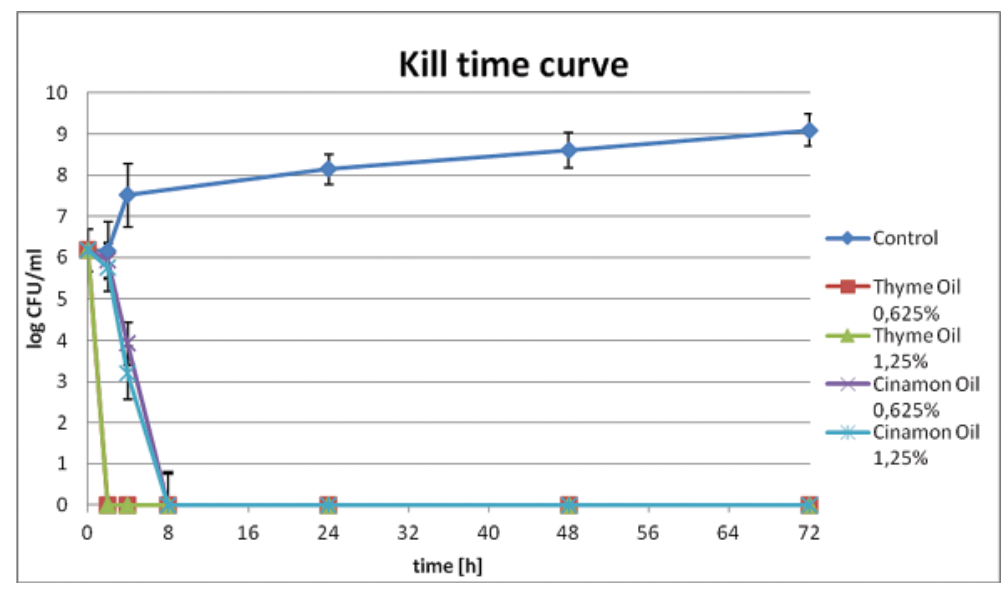

Figure 1. Time-kill assay

The considerable activity of the oils isolated from T. vulgaris, C. cassia and P. graveolens observed in our research is in agreement with the results presented by other authors. Thyme oil has been shown as effective in the treatment of antibiotic resistant staphylococci [21] and Tohidopour et al. [22] confirmed its high activity against MRSA isolates. The time - kill assay carried out in our laboratory revealed that ingredients of Thyme oil quickly eliminate staphylococci. However, it should be mentioned that in the case of 21 out of 31 strains tested a shift of $\mathrm{MBC}$ in comparison to MIC was 
observed. Thus it would be rather suggested to use this oil at a concentration at least two times higher than MIC.

High antimicrobial, including anti-staphylococcal, activity of the oil isolated from the bark of $C$. cassia has been previously revealed by the group of Ooi [23] and cinnamaldehyde was shown as a component crucial for its activity. Recently Melo and coworkers [24] confirmed the activity of both these oils (Thyme and Cinnamon) used as feed additives. Beside the fact that MIC values for both these products against S. aureus PCM 251 are exactly the same $(0.625 \%(\mathrm{v} / \mathrm{v}))$ the complete eradication of viable cells from the suspensions containing Cinnamon oil at a concentration equal to $\mathrm{MIC}$ or $2 \mathrm{xMIC}$ required 8 hours of incubation, in comparison to two hours in the case of Thyme oil. Thus, Thyme oil presents a much higher potential from the point of view of its application for treatment of infections or protection of food products.

Using the agar dilution method Bigos and coworkers [25] investigated the activity of Geranium oil obtained from P. graveolens Ait. (family Geraniaceae) against the group of 70 clinical isolates of $S$. aureus. All of the strains tested - including multidrug resistant strains, MRSA strains and MLS(B) - positive isolates - were found as highly susceptible to the components of this oil with MIC values of $0.25-2.50 \mu \mathrm{l} / \mathrm{ml}$. High activity of geranium oil against MRSA clinical isolates has been also confirmed by the group of Doran [26].

Interestingly, in comparison to Manuka honey, investigation of the antimicrobial efficiency of oil isolated from Leptospermum scoparium is definitely less popular. However, its high antimicrobial activity was described in 1999 by the group of Harkenthal [27], and Song and coworkers [28] revealed an excellent activity of Manuka oil against 50 Staphylococcus pseudointermedius isolates (39-methicillin resistant and 11 methicillin susceptible) from dogs. Recently the group of Fratini [29] found that the most representative compounds in Manuka essential oil are leptospermone (31.65\%), cis-calamenene $(15.93 \%)$ and flavesone $(6.92 \%)$, the authors confirmed also high antistaphylococcal activity of this product against fourteen $S$. aureus wild strains.

In our study especially high activity revealed Patchouli and Cedar oils obtained from P. cablin and J. virginiana, respectively. Broad antimicrobial, including antistaphylococcal potential of oils isolated from different species of Pogostemon was previously confirmed by Thoppil and colleagues [30]. Peng and coworkers [31] performed in vivo studies on the antimicrobial activity of pogostone - one of the Patchouli oil compounds. The authors found that $90 \%$ of the mice infected with E. coil were protected at the pogostone doses of 50 and $100 \mathrm{mg} / \mathrm{kg}$, and $60 \%$ of the mice at $25 \mathrm{mg} / \mathrm{kg}$, while the rate of protection for the mice infected with MRSA was $60 \%$ and $50 \%$ at doses of 100 and $50 \mathrm{mg} / \mathrm{kg}$, respectively. The group of Bilcu [32] successfully used Patchouli oil for development of nanobiosystems that could be used as coatings for catheter pieces with an improved resistance to $S$. aureus and Klebsiella pneumoniae clinical strains adherence and biofilm development. The considerable antibiofilm activity of Patchouli oil was also observed by Vazquez-Sanchez and coworkers [33]. Surprisingly data concerning antistaphylococcal potential of Cedar oil are limited to date. 
The results presented by other authors suggest that some other products from the 36 initially screened oils, e. g. Tea tree oil [34] or Lavender oil [35] should exhibit a high antimicrobial activity, but they were found to be not efficient in the treatment of staphylococci. This observation can be explained by large differences in chemical compositions (concentration of ingredients responsible for the biological activity) of oils produced from raw materials growing in different geographical areas or different weather or environmental conditions. This phenomenon is an important drawback of essential oils (and other natural products) from the point of view of their application in the treatment or prophylaxis of human and animal infectious diseases.

The results of our research clearly indicate that some essential oils exhibit a promising antimicrobial activity, especially against $S$. aureus. Previously we have also confirmed a high antifungal potential of some of these oils. Especially high activity was observed for Lemon, Basil, Thyme, Geranium, Cinnamon and Clove oils [20]. In our opinion, currently the antimicrobial potential of essential oils, but also many other natural products (plant extracts, propolis, honey) is under-utilized and undervalued [16]. There are many possibilities of application of these products in treatment but also, prophylaxis of infections caused by microorganisms. The oils could be more commonly used as components of: wound dressing materials, cosmetics, liquids used for washing injuries or medical devices, food supplements, feeds, but they also could be applied instead of antibiotics for treating less dangerous, not life-threatening diseases (e.g. skin infections). The observed rapidly growing number of antibiotic-resistant strains is mainly a consequence of the abuse of this group of chemotherapeutics. This phenomenon is especially common among staphylococci. In our opinion the main benefit coming from more widespread using of essential oils would be reduced using of antibiotics. Consequently the development of antibiotic resistance could be partially limited.

\section{CONCLUSIONS}

Essential oils have a potential for further development of antibiotic alternatives for treatment of staphylococcal infections and useful tools to enhance food security.

\section{Acknowledgments}

The research was founded by the National Science Center (Grant no. UMO2012/07/N/NZ9/00939), moreover one of the authors Magdalena Zalewska received funding for the preparation of the doctoral dissertation from the National Science Center in the framework of a doctoral scholarship funding based on the decision number DEC-2014/12/T/NZ9/00534.

\section{Authors' contributions}

The idea for the paper was conceived by SzP and ZM. The experiments were designed by SzP, ZM and KB. The experiments were performed by ZM, PJ and SzP. The data 
were analyzed by SzP, ZM, PJ, MS and KB. The paper was written by SzP and MZ. The manuscript was critically revises for important intellectual content by SzP, KB and MS. All authors read and approved the final version of the manuscript.

\section{Declaration of conflicting interests}

The author(s) declared no potential conflicts of interest with respect to the research, authorship, and/or publication of this article.

\section{REFERENCES}

1. Bochniarz M, Wawron W: Antibiotic susceptibility of methicillin-resistant and methicillinsusceptible coagulase-negative staphylococci isolated from bovine mastitis. Pol J Vet Sci 2011, 14(3): 405-410.

2. Bochniarz M, Adaszek L, Dzięgiel B, Nowaczek A, Wawron W, Dąbrowski R, Szczubiał M, Winiarczyk S: Factors responsible for subclinical mastitis in cows caused by Staphylococcus chromogenes and its susceptibility to antibiotics based on bap, fnbA, eno, mecA, tetK, and ermA genes. J Dairy Sci 2016, 99(12): 9514-9520.

3. Jagielski T, Puacz E, Lisowski A, Siedlecki P, Dudziak W, Międzobrodzki J, Krukowski H: Antimicrobial susceptibility profiling and genotyping of Staphylococcus aureus isolates from bovine mastitis in Poland. J Dairy Sci 2014, 97(10): 6122-6128.

4. Kot B, Piechota M, Wolska KM, Frankowska A, Zdunek E, Binek T, Kłopotowska E, Antosiewicz M: Phenotypic and genotypic antimicrobial resistance of staphylococci from bovine milk. Pol J Vet Sci 2012, 15(4): 677-683.

5. Kot B, Piechota M, Antos-Bielska M, Zdunek E, Wolska KM, Binek T, Olszewska J, Guliński P, Trafny EA: Antimicrobial resistance and genotypes of staphylococci from bovine milk and the cowshed environment. Pol J Vet Sci 2012, 15(4): 741-749.

6. Szweda P, Schielmann M, Frankowska A, Kot B, Zalewska: Antibiotic resistance in Staphylococcus aureus strains isolated from cows with mastitis in eastern Poland and analysis of susceptibility of resistant strains to alternative nonantibiotic agents: lysostaphin, nisin and polymyxin B. J Vet Med Sci 2014, 76(3): 355-362.

7. Nascimento JS, Ceotto H, Nascimento SB, Giambiagi-Demarval M, Santos KR, Bastos MC: Bacteriocins as alternative agents for control of multiresistant staphylococcal strains. Lett Appl Microbiol 2006, 42: 215-221.

8. Szweda P, Schielmann M, Kotlowski R, Gorczyca G, Zalewska M, Milewski S: Peptidoglycan hydrolases-potential weapons against Staphylococcus aureus. Appl Microbiol Biotechnol 2012, 96: 1157-1174.

9. Matsuzaki S, Yasuda M, Nishikawa H, Kuroda M, Ujihara T, Shuin T, Shen Y, Jin Z, Fujimoto S, Nasimuzzaman MD, Wakiguchi H, Sugihara S, Sugiura T, Koda S, Muraoka A, Imai S: Experimental protection of mice against lethal Staphylococcus aureus infection by novel bacteriophage phi MR11. J Infect Dis 2003, 187: 613-624.

10. Sulakvelidze A, Alavidze Z, Morris JG: Bacteriophage therapy. Antimicrob Agents Chemother 2001, 45: 649-659. 
11. Desbois AP, Gemmell CG, Coote PJ: In vivo efficacy of the antimicrobial peptide ranalexin in combination with the endopeptidase lysostaphin against wound and systemic meticillinresistant Staphylococcus aureus (MRSA) infections. Int J Antimicrob Agents 2010, 35: 559-565.

12. Korkina LG: Phenylpropanoids as naturally occurring antioxidants: from plant defense to human health. Cell Mol Biol 2007, (Noisy-le-grand) 53: 15-25.

13. Mayaud L, Carricajo A, Zhiri A, Aubert G: Comparison of bacteriostatic and bactericidal activity of 13 essential oils against strains with varying sensitivity to antibiotics. Lett Appl Microbiol 2008, 47: 167-173.

14. Orhan DD, Ozçelik B, Ozgen S, Ergun F: Antibacterial, antifungal, and antiviral activities of some flavonoids. Microbiolo Res 2010, 165: 496-504.

15. Ewnetu Y, Lemma W, Birhane N: Antibacterial effects of Apis mellifera and stingless bees honeys on susceptible and resistant strains of Escherichia coli, Staphylococcus aureus and Klebsiella pneumoniae in Gondar, Northwest Ethiopia. BMC Complement Altern Med 2013, 13: 269.

16. Szweda P, Kot B: Bee products and essential oils as alternative agents for treatment of infections caused by $S$. aureus, Frontiers in Staphylococcus aureus, Dr. Shymaa Enany (Ed.), InTech 2016, DOI: 10.5772/65978.

17. Wojtyczka RD, Dziedzic A, Idzik D, Kepa M, Kubina R, Kabała-Dzik A, Smolen-Dzirba J, Stojko J, Sajewicz M, Wasik TJ: Susceptibility of Staphylococcus aureus clinical isolates to propolis extract alone or in combination with antimicrobial drugs. Molecules 2013, 18: 9623-9640.

18. Kurlenda J, Grinholc M: Alternative therapies in Staphylococcus aureus diseases. Acta Bioch Pol 2012, 59: 171-184.

19. Bakkali F, Averbeck S, Averbeck D, Idaomar M: Biological effects of essential oils - A review. Food Chem Toxicol 2008, 46: 446-475.

20. Szweda P, Gucwa K, Kurzyk E, Romanowska E, Dzierżanowska-Fangrat K, ZielińskaJurek A, Kuś PM, Milewsk S: Essential Oils, Silver Nanoparticles and Propolis as Alternative Agents Against Fluconazole Resistant Candida albicans, Candida glabrata and Candida krusei Clinical Isolates. Indian J Microbiol 2015, 55: 175-183.

21. Shin S, Kim JH: In vitro inhibitory activities of essential oils from two Korean thymus species against antibiotic-resistant pathogens. Arch Pharm Res 2005, 28: 897-901.

22. Tohidpour A, Sattari M, Omidbaigi R, Yadegar A, Nazemi J: Antibacterial effect of essential oils from two medicinal plants against Methicillin-resistant Staphylococcus aureus (MRSA). Phytomedicine 2010, 17: 142-145.

23. Ooi LSM, Li Y, Kam S-L, Wang H, Wong EY, Ooi VE: Antimicrobial activities of cinnamon oil and cinnamaldehyde from the Chinese medicinal herb Cinnamomum cassia Blume. Am J Chin Med 2006, 34: 511-522.

24. Melo ADB, Amaral AF, Schaefer G, Luciano FB, de Andrare C, Costa LB, Rostagno MH: Antimicrobial effect against different bacterial strains and bacterial adaptation to essential oils used as feed additives. Can J Vet Res 2015, 79: 285-289.

25. Bigos M, Wasiela M, Kalemba D, Sienkiewicz M: Antimicrobial activity of geranium oil against clinical strains of Staphylococcus aureus. Molecules 2012, 7(9):10276-10291

26. Doran AL, Morden WE, Dunn K, Edwards-Jones V: Vapour-phase activities of essential oils against antibiotic sensitive and resistant bacteria including MRSA. Lett Appl Microbiol 2009, 48(4): 387-392. 
27. Harkenthal M, Reichling J, Geiss HK, Saller R: Comparative study on the in vitro antibacterial activity of Australian tea tree oil, cajuput oil, niaouli oil, manuka oil, kanuka oil, and eucalyptus oil. Pharmazie 1999, 54: 460-463.

28. Song C-Y, Nam E-H, Park S-H, Hwang C-Y: In vitro efficacy of the essential oil from Leptospermum scoparium (manuka) on antimicrobial susceptibility and biofilm formation in Staphylococcus pseudintermedius isolates from dogs. Vet Dermatol 2013, 24: 404-408.

29. Fratini F, Mancini S, Turchi B, Friscia E, Pistelli L, Giusti G, Cerri D: A novel interpretation of the Fractional Inhibitory Concentration Index: The case Origanum vulgare L. and Leptospermum scoparium J. R. et G. Forst essential oils against Staphylococcus aureus strains. Microbiol Res 2017, 195: 11-17.

30. Thoppil JE, Tajo A, Minija J, Deena MJ, Sreeranjini K, Leeja L, Sivadasan M, Alfarhan AH: Antimicrobial activity of the essential oils of three species of Pogostemon. J Environ Biol 2014, 35(5): 795-798.

31. Peng F, Wan F, Xiong L, Peng C, Dai M, Chen J: In vitro and in vivo antibacterial activity of Pogostone. Chin Med J (Engl) 2014, 127(23): 4001-4005.

32. Bilcu M, Grumezescu AM, Oprea AE, Popescu RC, Mogoșanu GD, Hristu R, Stanciu GA, Mihailescu DF, Lazar V, Bezirtzoglou E, Chifiriuc MC: Efficiency of vanilla, patchouli and ylang ylang essential oils stabilized by iron oxide@C14 nanostructures against bacterial adherence and biofilms formed by Staphylococcus aureus and Klebsiella pneumoniae clinical strains. Molecules 2014, 19(11): 17943-17956.

33. Vázquez-Sánchez D, Cabo ML, Rodríguez-Herrera JJ: Antimicrobial activity of essential oils against Staphylococcus aureus biofilms. Food Sci Technol Int 2015, 21(8): 559-570.

34. Carson CF, Cookson BD, Farrelly HD, Riley TV: Susceptibility of methicillin-resistant Staphylococcus aureus to the essential oil of Melaleuca alternifolia. J Antimicrob Chemother 1995, 35(3): 421-424.

35. Roller S, Ernest N, Buckle J: The antimicrobial activity of high-necrodane and other lavender oils on methicillin-sensitive and -resistant Staphylococcus aureus (MSSA and MRSA). J Altern Complement Med 2009, 15(3): 275-279.

\title{
ETERIČNA ULJA SA ANTISTAFILOKOKNIM POTENCIJALOM
}

\author{
SZWEDA Piotr, ZALEWSKA Magdalena, PILCH Joanna, KOT Barbara, \\ MILEWSKI Sławomir
}

Antibiotska terapija stafilokoknih mastitisa se karakteriše značajno malim uspehom u poređenju sa terapijom ostalih oboljenja, bakterijske etiologije. Otuda je neophodno da se obavljaju ispitivanja novih, alternativnih supstanci koje ne spadaju u kategoriju antibiotika, a koje su efikasne. Cilj studije je bio da se ispitaju antimikrobna, a naročito antistafilokokna svojstva većeg broja $(n=36)$ eteričnih ulja $(E O)$. Ispitivanje antimikrobnih svojstava testiranih ulja su odredivana korišćenjem dvostrukih serijskih razređenja, u mikrotitar pločama (96 mesta), u preporučenim uslovima od strane Instituta za kliničku i laboratorijsku standardizaciju (CLSI). Preliminarni rezultati su pokazali da šest ulja: manuka, majčina dušica, geranijum, kedar, cimet kao i pačuli 
poseduju najveću aktivnost u odnosu na referentni soj bakterija. Značajan antistafilokokni potencijal ovih ulja je potvrđen i u testovima u kojima su korišćene grupe bakterije kao što su Staphylococcus aureus (osamnaest), osam Staphylococcus epidermidis i pet Staphylococcus xylosus, koje su izolovane iz uzoraka poreklom od krava sa mastitisom. Naročito je značajna bila aktivnost ulja kedra, pačuli, majčine dušice i manuka. Vrednosti minimalnih inhibitornih koncentracija (MIC) za pačuli ulje bile su u rasponu od 0,01 do $0,313 \%$ (v/v). Ostala tri ulja su pokazivala antimikrobnu aktivnostu u koncentracijama od 0,01 do 0,625\% (v/v). Ulja koja su izdvojena od Cinnamomum cassia i Pelargonium graveolens, pokazivala su manju ali ipak i dalje značajnu i zadovoljavajuću antimikrobnu aktivnost pri čemu je MIC bila u rasponu od 0,02 do 1,25\% (v/v) i od 0,078 do 1,25\% (v/v). U većini slučajeva, da bi se dobio baktericidni efekat, bilo je neophodno da se koncentracija ulja neznatno poveća u odnosu na koncentraciju koja je kao efekat imala inhibiciju rasta bakterija. Kinetičke studije baktericidnog efekata u odnosu na vreme delovanja, pokazale su da je baktericidni efekat postignut posle inkubacije referentnog soja $S$. aureus (PCM 5021) sa uljem majčine dušice, u koncentraciji dvostruko većoj u odnosu na MIC (2xMIC tj. 1,25\% v/v) ili MIC (0,625\% v/v). Neznatno slabija aktivnost je bila u slučaju cimetovog ulja kada je baktericidni efekat uočen posle inkubacije u trajanju od 8 sati. Rezultati jasno ukazuju da neka eterična ulja imaju antimikrobna svojstva i da mogu da se koriste kao alternativa ostalim antistafilokoknim preparatima. 